\title{
GAYA HIDUP NGOPI SEBAGAI PERILAKU KONSUMSI
}

\author{
Profil Yugantara, Rachmad K. Dwi Susilo, Sulismadi \\ Fakultas Ilmu Sosial dan Ilmu Politik, Universitas Muhammadiyah Malang, Indonesia \\ profilyugantara@gmail.com, rachmad@umm.ac.id, sulismadi@gmail.com
}

Received: 11-12-2020 Revised: 10-01-2021 Accepted: 27-01-2021

\section{Ngopi Lifestyle as a Consumption Behavior}

\begin{abstract}
So many coffee shop in Malang have recently been able to create a new lifestyle for some people who we usually hear about ngopi. Ngopi activities are not necessarily limited to drinking coffee and so on, but there are activities of consumsing symbols that can provide messages or signs for individuals who consume them and other people who see them. This study aims to describe the ngopi lifestyle as a consumption behavior in the people of Malang City. This research method uses descriptive qualitative with the technique of determining the research subject using accidental sampling. Based on the result of the research that ngopi is currently an icon of modern lifestyle and in the ngopi lifestyle there are consumption behaviors that aim to gain prestige, images, social status and consciously or unconsciously that will differentiate individuals from others. Starting from a public capture of simulations made by brands, it is able to distort our minds that is not real becomes real. That way, raises a distinction or process of classifying the tastes of individuals or groups, in a grouping of taste in which there are classifications in an individual or group.
\end{abstract}

Keywords: Consumption Behavior, Icon, Ngopi, Symbol.

\begin{abstract}
Abstrak
Menjamurnya kedai kopi di Kota Malang belakangan tahun ini mampu menciptakan sebuah gaya hidup baru pada sebagian masyarakat yang biasa kita dengar ngopi. Kegiatan ngopi tidak serta merta sebatas minum kopi dan sebagainya, melainkan terdapat kegiatan mengonsumsi simbol yang mampu memberikan pesan atau tanda bagi individu yang mengonsumsi dan orang lain yang melihatnya. Penelitian ini bertujuan untuk mendeskripsikan tentang gaya hidup ngopi sebagai perilaku konsumsi di masyarakat Kota Malang. Metode penelitian ini menggunakan kualitatif deskriptif dengan teknik penentuan subjek penelitian menggunakan accidental sampling. Berdasarkan hasil penelitian bahwa ngopi pada saat ini merupakan sebuah icon gaya hidup modern dan dalam gaya hidup ngopi terdapat perilaku konsumsi yang bertujuan untuk mendapatkan prestise, gengsi, images, status sosial dan secara sadar atau tidak sadar yang akan membedakan diri individu dengan orang lain. Berawal dari sebuah penangkapan masyarakat terhadap simulasi yang dibuat oleh brand, hal tersebut mampu mendistorsi alam pikiran kita bahwasanya yang tidak nyata menjadi nyata. Dengan begitu, memunculkan sebuah distingsi atau proses pengelompokkan selera terhadap individu atau kelompok, dalam sebuah pengelompokkan selera yang mana terjadi sebuah klasifikasi-klasifikasi kelas pada suatu individu atau kelompok.
\end{abstract}

Kata Kunci : Icon, Ngopi, Perilaku Konsumsi, Simbol. 


\section{PENDAHULUAN}

Masyarakat postmodern adalah masyarakat yang mengutamakan konsumsi ${ }^{1}$. Masyarakat postmodern tidak lagi mengonsumsi benda berdasarkan manfaat atau fungsinya, tetapi mengonsumsi benda berdasarkan tanda, simbol, dan gengsi. Melalui objek ini, setiap orang dan setiap kelompok dapat menemukan tempatnya dalam masyarakat.

Perilaku konsumsi dalam masyarakat yang terjadi pada era globalisasi ini tidak hanya untuk memenuhi nilai fungsional, tetapi juga untuk memenuhi kebutuhan nilai simbolik ${ }^{2}$. Disini, perubahan konsumsi yang terjadi terhadap sebagian masyarakat dapat diartikan bahwa konsumsi masyarakat tidak hanya sebagai permintaan, akan tetapi juga sebagai permintaan untuk memuaskan gengsi. perilaku konsumsi yang dimaksud disini yakni ngopi yang menjadikan hal tersebut menjadi sebuah gaya hidup pada sebagian masyarakat saat ini.

Jika dalam perspektif modernisme konsumsi dilakukan dengan mempertukarkan uang dengan barang dan jasa. Namun, dalam masyarakat posmodernisme pada proses konsumsi, secara paradoks menggabungkan antara kenyataan dan imajinasi, dimana seseorang dapat mengonsumsi obyek, simbol, dan image secara bersamaan, yang menjadi ciri khas masyarakat konsumsi adalah universal serba-serbi dalam komunikasi massa ${ }^{3}$. Semua informasi politik, sejarah, budaya, diterima dalam bentuk yang sama, sekaligus tidak penting dan menakjubkan diabndingkan dengan berita serba-serbi. Semua informasi diaktualkan, artinya dibuat dramatis engan cara spektakuler-semua tidak diaktualkan, artinya dibatasi oleh media komunikasi dan direduksi dengan tanda-tanda. Sehingga, berita serba-serbi bukan merupakan kategori lain tetapi kategori utama dari pemikiran magis kita dan mitologi kita ${ }^{4}$.

Menjamurnya kedai-kedai kopi yang memiliki nama brand besar yang berada di pusat perbelanjaan atau mall seperti Starbucks, J'Co Donuts and Coffee, lalu Excelso dan lain sebagainya. Mampu mengendalikan selera bagi sebagian masyarakat ketika ingin melakukan kegiatan ngopi. Pada saat ini dengan begitu banyaknya kedai kopi di Kota Malang memperlihatkan bahwasanya ngopi saat ini telah menjadi sebuah gaya hidup baru. Kedai kopi tidak hanya semata-mata sebagai tempat untuk ngopi saja, melainkan saat ini telah menjadi tempat berkumpulnya anak muda, tempat pertemuan (meeting), dan kegiatan-kegiatan lainnya.

Perilaku yang dimaksud disini yakni ngopi yang menjadikan hal tersebut menjadi sebuah gaya hidup. Pada sebagian masyarakat budaya ngopi bukan lagi hanya sekedar minum kopi dan lainnya, melainkan terdapat sebuah rutinitas yang tertata rapi pada diri individu dan sebuah tuntulan selera bagi sebagian masyarakat perkotaan. Pada kenyataannya budaya ngopi telah mengalami pergeseran yang mana bisa kita lihat sebagian masyarakat sering kali menghabiskan

\footnotetext{
${ }^{1}$ George Ritzer \& Douglas Goodman, Teori Sosiologi Modern (Jakarta: Kencana, 2003). Hal 372.

${ }^{2}$ Ken Peattie, "Green consumption: behavior and norms," Annual review of environment and resources 35 (2010): 195-228; J. Niels Rosenquist dkk., "The spread of alcohol consumption behavior in a large social network," Annals of internal medicine 152, no. 7 (2010): 426-33; Leon Shiffman, Leslie Kanuk, dan Havard Hansen, Consumer Behavior: A European Outlook (Prentice Hall, 2008).

3 Stanley J. Baran, "Introduction to mass communication," 2015; Sara Ahmadian, Sara Azarshahi, dan Delroy L. Paulhus, "Explaining Donald Trump via Communication Style: Grandiosity, Informality, and Dynamism," Personality and Individual Differences $107 \quad$ (1 Maret 2017): 49-53, https://doi.org/10.1016/j.paid.2016.11.018; Kasper Welbers dan Michaël Opgenhaffen, "Presenting News on Social Media," Digital Journalism 7, no. 1 (2 Januari 2019): 45-62, https://doi.org/10.1080/21670811.2018.1493939.

${ }^{4}$ Jean P Baudrillard, Masyarakat Konsumsi (Yogyakarta: Kreasi Wacana, 2004). Hal 17.
} 
waktu di kedai kopi hanya untuk sekedar mengisi kekosongan waktu, beristirahat sambil menikmati hidangan dan hal tersebut dilakukan secara berulang kali sehingga menjadikannya sebuah gaya hidup bagi sebagian masyarakat untuk saat ini.

Gaya hidup merupakan ciri sebuah dunia modern atau yang biasa juga disebut modernitas. Maksudnya adalah siapa pun yang hidup dalam masyarakat modern akan menggunakan gagasan tentang gaya hidup untuk menggambarkan tindakannya sendiri maupun orang lain. gaya hidup adalah pola-pola tindakan yang membedakan antara satu orang dengan orang lain ${ }^{5}$. Dalam masyarakat kontemporer, perilaku konsumsi juga dicirikan dengan pemanfaatan waktu luang, dimana waktu luang menjadi kebutuhan bagi individu, bukan hanya dimanfaatkan untuk istirahat sebentar dari rutinitas pekerjaan, akan tetapi juga sebagai mengekspresikan simbol dan gaya hidup ${ }^{6}$. Dalam masyarakat konsumsi, masyarakat akan menggunakan waktu luang untuk perilaku konsumsi, hal ini menurut Thorstein Veblen disebut sebagai the leisure class atau kelas pemboros. Kata leisure berarti "waktu luang" dan class berarti "kelas", maka istilah "leisure class" dpat diterjemahkan dengan "kelas pemboros". Mereka memboroskan uang, waktu, tenaga kerja, dan menikmati gengsi serta status tinggi karenanya ${ }^{7}$. Oleh karena itu, dalam gaya hidup masyarakat konsumsi, kehidupan sehari-hari cenderung untuk menunjukkan identitas diri. Mereka menghabiskan banyak waktu dan biaya yang tidak sedikit untuk memenuhi gaya hidup ngopi. Perilaku konsumsi yang terjadi bukan hanya untuk kepuasan diri melainkan sebagai alat menunjukkan identitas diri demi mendapatkan prestise, dan bertujuan untuk meningkatkan citra dan status sosial ${ }^{8}$.

Tema ini layak diteliti karena menurut peneliti fenomena ngopi telah menjadi sebuah gaya hidup atau lifestyle di masyarakat perkotaan. Hal tersebut terjadi di Kota Malang, yang mana masyrakatnya lebih suka ngopi di kedai-kedai kopi baik dalam pusat perbelanjaan (mall) maupun di pinggir jalan, dibandingkan ngopi dirumah. Jika dilihat dari perspektif postmodernisme masyarakat tidak hanya mengonsumsi kopi atau produk lainnya saja, melainkan terdapat nilai-nilai tanda, simbol, dan image yang dikonsumsi secara bersamaan, serta pada waktu itulah individu dapat mempresentasikan siapa dirinya. Dengan adanya penelitian ini, peneliti berharap dapat menggambarkan fakta-fakta bahwasanya perubahan masyarakat yang secara tidak merata yaitu menuju masyarakat postmodern.

Saat ini di sekitar kita terdapat semacam kenyataan yang luar biasa tentang konsumsi dan kelimparuahan yang dibentuk oleh melimpahnya objek, jasa, barang-barang-barang material yang kemudian membentuk sejenis mutasi fundamental dalam ekologi kemanusiaan. Makna yang sebenarnya dengan jujur kami katakan bahwa orang-orang kaya tidak lagi

${ }^{5}$ David Chaney, Lifestyle : Sebuah Pengantar Komprehensif, Penerjemah (Yogyakarta: Jalasutra, 1996). Hal 40.

${ }^{6}$ Hartiyani Sadu Budanti, Mintasih Indriayu, dan Muhammad Sabandi, "Pengaruh lingkungan sosial dan gaya hidup terhadap perilaku konsumsi mahasiswa program studi pendidikan ekonomi FKIP UNS," Jurnal Pendidikan Bisnis Dan Ekonomi 3, no. 2 (2017); M. Chairul Basrun Umanailo, Mansyur Nawawi, dan Sukainap Pulhehe, "Konsumsi Menuju Konstruksi Masyarakat Konsumtif," Simulacra 1, no. 2 (2018): 203-12.

${ }^{7}$ K.J Veeger, Realitas Sosial Refleksi Filsafat Sosial Atas Hubungan Individu-Masyarakat Dalam Cakrawala Sejarah Sosiologi (Jakarta: PT Gramedia, 1986). Hal 105.

8 Mahyuddin Mahyuddin, "Social Climber Dan Budaya Pamer: Paradoks Gaya Hidup Masyarakat Kontemporer," Jurnal Kajian Islam Interdisipliner 2, no. 2 (2019); Bagong Suyanto, Sosiologi ekonomi: Kapitalisme dan konsumsi di era masyarakat post-modernisme (Prenada Media, 2014); Solikatun Solikatun, Drajat Tri Kartono, dan Argyo Demartoto, "Perilaku Konsumsi Kopi Sebagai Budaya Masyarakat Konsumsi (Studi Fenomenologi Pada Peminum Kopi Di Kedai Kopi Kota Semarang)," Jurnal Analisa Sosiologi 4, no. 1 (2015). 
dikelilingi oleh orang lain tetapi dikelilingi oleh objek ${ }^{9}$. Sebagai contoh, ketika individu atau kelompok berada di dalam pusat perbelanjaan (mall) mereka tidak perlu bingung untuk menentukan apa yang mereka inginkan karena semua tersedia di dalamnya, semua berjajar dengan rapi dan menawarkan berbagai macam brand, jenis, dan lain sebagainya.

Masyarakat konsumsi akan membeli simbol-simbol atau tanda yang melekat pada suatu objek, sehingga objek-objek konsumsi banyak yang terkikis nilai guna dan nilai tukarnya. Nilai tanda dan nilai simbol kemudian menjadi sebuah komoditas. Untuk menjadi objek konsumsi, suatu objek harus menjadi tanda (sign), karena hanya dengan cara demikian objek tersebut dapat dipersonalisasikan dan dapat dikonsumsi.

Konsep simulasi Jean P Baudrillard adalah tentang menciptakan kenyataan/realitas melalui model-model konseptual atau hal-hal yang berkaitan dengan "mitos" yang faktanya tidak dapat dilihat dalam kenyataan/realitas, dengan kata lain: hiperrealitas atau realitas semu. Simulacra telah dijadikan cara untuk memenuhi kebutuhan masyarakat konsumsi akan tanda dan sebagai masyarakat yang terbanjiri oleh citra dan informasi yang ada, maka simulasi telah membuat citra menjadi suatu hal yang paling diminati dan diperhatikan dalam kebudayaan masyarakat pascamodern. Kemudian dari sinilah realitas dihasilkan melalui simulasi berbasis model-model (yang tidak memiliki asal-usul atau referensi realitas) dan secara artifisial direproduksi sebagai kenyataan ${ }^{10}$.

Sadar atau tidak sadar, masyarakat saat ini memiliki kecenderungan kearah masyarakat konsumsi. Hal tersebut dapat ditinjau dari gaya berpakaian, jenis handphone yang digunakan, kendaraan yang dijadikan sebagai transportasi pribadi, serta tempat nongkrong (ngopi) yang dikunjungi, dianggap dapat mempresentasikan dirinya. Fenomena masyarakat konsumsi dalam hal ngopi terjadi karena adanya perubahan mendasar berkaitan dengan cara individu atau kelompok mengekspresikan diri dalam gaya hidupnya. hal ini berlandaskan logika konsumsi masyarakat yang telah berubah, yang mana logika yang mendasarinya bukan lagi logika kebutuhan (need) melainkan logika hasrat (desire).

\section{METODE PENELITIAN}

Metode penelitian yang dilakukan adalah menggunakan pendekatan penelitian kualitatif. Penelitian kualitatif adalah salah satu metode penelitian yang dilakukan dalam situasi yang sewajarnya (natural setting), data yang dikumpulkan biasanya bersifat kualitatif. Metode penelitian kualitatif mencoba memahami dan menjelaskan makna peristiwa yang berinteraksi dengan perilaku manusia dalam situasi tertentu berdasarkan sudut pandang peneliti sendiri ${ }^{11}$.

Dapat diartikan bahwa penelitian kualitatif adalah penelitian yang menekankan pada situasi yang alamiah (naturalistic) yang melihat suatu fenomena secara apa adanya. Dalam penelitian kualitatif peneliti mengamati, menginterpretasi, serta berinteraksi secara langsung dengan subjek penelitian secara alamiah (naturalistic).

Berdasarkan permasalahan yang diangkat dalam penelitian mengenai gaya hidup ngopi sebagai perilaku konsumsi maka, jenis penelitian yang digunakan adalah jenis penelitian deskriptif. Penelitian deskriptif merupakan penelitian untuk memberikan uraian mengenal

${ }^{9}$ Baudrillard, Masyarakat Konsumsi. Hal 3.

${ }^{10}$ Chris Barker, Cultural Studies (Bantul: Kreasi Wacana, 2011). Hal 166. Hal 78.

${ }^{11}$ Husaini \& Akbar Setiady Purnomo Usman, Metodologi Penelitian Sosial (Jakarta: PT Bumi Aksara, 2008). 
fenomena atau gejala sosial yang diteliti dengan mendeskripsikan tentang nilai variabel mandiri, baik satu variabel atau lebih berdasarkan indikator-indikator dari variabel yang diteliti tanpa membuat perbandingan atau menghubungkan antara variabel yang diteliti untuk eksplorasi dan klarifikasi dengan variabel yang diteliti ${ }^{12}$.

Penelitian dilakukan di sebuah kedai kopi dan yang akan menjadi lokasi penelitian adalah Starbucks yang berada di pusat perbelanjaan (mall) yakni Malang City Point. Kenapa memilih kedai kopi starbucks, karena merupakan kedai kopi terkenal yang mana starbucks merupakan brand internasional yang telah menjadi ikon gaya hidup ngopi modern yang saat ini menjadi budaya populer.

Teknik penentuan subjek dalam penelitian ini menggunakan Accidental Sampling. Accidental Sampling merupakan teknik pengambilan sampel yang didasarkan pada kebetulan, artinya konsumen yang bertemu dengan peneliti secara kebetulan/tidak sengaja dapat dijadikan sampel, apabila menurut peneliti memandang bahwa orang yang kebetulan ditemui tersebut cocok dijadikan sebagai sumber data ${ }^{13}$.

Teknik pengumpulan data dalam penelitian ini menggunakan data primer dan data sekunder yang mana pada data primer peneliti melakukan observasi. Disini, peneliti datang serta melakukan kegiatan ngopi di kedai kopi starbucks sambil mengamati kegiatan-kegiatan yang dilakukan oleh para penggiat ngopi. Lalu, peneliti melakukan wawancara kepada penggiat ngopi hingga peneliti mendapatkan data yang lengkap. Sedangkan data sekunder merupakan sumber data penelitian yang diperoleh oleh peneliti yang bersifat tidak langsung atau melalui media perantara. Data sekunder dapat berupa dokumentasi yang berkaitan dengan subjek penelitian, catatan-catatan penunjang, literature, buku-buku, dan jurnal.

Dalam teknik analisa data melalui reduksi data yaitu proses pemilihan, pemfokusan, penyederhaan, pengabstrakan, dan transformasi data mentah yang ada pada catatan lapangan tertulis. Lalu penyajian data yakni suatu kegiatan ketika sekumpulan informasi disusun. Bentuk penyajian data kualitatif adalah berupa teks naratif dan catatan lapangan atau peristiwa itu terjadi di masa lampau. Dan terakhir penarikan kesimpulan, proses penarikan kesimpulan merupakan bagian penting dari kegiatan penelitian, karena merupakan kesimpulan dari sebuah penelitian. Tujuan dari kesimpulan ini adalah untuk menganalisa serta mencari makna dari data yang ada sehingga dapat ditemukan permasalahan apa yang ada dalam penelitian yang telah dilakukan ${ }^{14}$.

Uji keabsahan data yang diutamakan adalah menggunakan teknik trianggulasi. Trianggulasi dalam pengujian kredibilitas ini dapat diartikan sebagai pengecekan data dari berbagai sumber dengan berbagai cara dan waktu. Dengan demikian dalam teknik trianggulasi terdapat trianggulasi sumber, trianggulasi teknik, dan trianggulasi waktu. Untuk menguji keabsahan data, peneliti menggunakan trianggulasi waktu yaitu pengujian kredibilitas data dapat dilakukan dengan cara melakukan pengecekan dengan wawancara, observasi, atau teknik lain dalam waktu atau situasi yang berbeda ${ }^{15}$.

\footnotetext{
12 Hamid Darmadi, Metode Penelitian Pendidikan dan Sosial (Bandung: Alfabeta, 2014). Hal 185.

13 Sugiyono, Metode Penelitian Pendidikan (Pendekatan Kuantitatif, Kualitatif, dan R $\omega D$ ) (Bandung: Alfabeta, 2014). Hal 85.

${ }^{14}$ Aan Satori, Djam'an \& Komariah, Metodologi Penelitian Kualitatif (Bandung: Alfabeta, 2009). Hal 39.

15 Sugiyono, Metode Penelitian Pendidikan (Pendekatan Kuantitatif, Kualitatif, dan R\&D). Hal 274.
} 


\section{HASIL DAN PEMBAHASAN}

Gaya hidup bisa diartikan sebagai sebuah tindakan yang dapat membantu memahami yakni menggambarkan atau menjelaskan namun bukan berarti membenarkan apa yang orang lakukan, mengapa mereka melakukannya, dan apakah yang mereka lakukan bermakna bagi dirinya maupun orang lain. perilaku konsumsi (ngopi) sekarang ini telah menjadi suatu kebiasaan atau budaya masyarakat atau merupakan bagian dari gaya hidup untuk sebagian masyarakat. dalam melakukan aktivitas ngopi tampak berbagai kegiatan yang dilakukan oleh individu atau kelompok, antara lain: menikmati suasana kedai kopi, mengerjakan tugas dan pekerjaan, bercengkerama dengan teman-teman dan melakukan pertemuan (meeting). Hal tersebut karena pelanggan kedai kopi starbucks memiliki rasa kecocokan akan tempat, suasana, pelayanan, serta produk-produk dari kedai kopi starbucks itu sendiri.

Starbucks merupakan sebuah kedai kopi dengan brand internasional yang mana seluruh dunia tahu akan kedai kopi tersebut. Brand tersebut berdiri di berbagai belahan dunia tak terkecuali Indonesia, starbucks begitu diminati oleh sebagian masyarakat Indonesia ketika ingin melakukan kegiatan ngopi. Untuk menjadikan sebuah brand yang terkenal tidaklah mudah seperti membalikkan telapak tangan, butuh waktu yang cukup lama serta konsistensi akan kualitas produknya sehingga masyarakat dunia mengenal starbucks.

Proses membangun sebuah brand tidak serta merta hanya dari mulut ke mulut saja, akan tetapi pada era digital seperti yang terjadi saat ini dimana media seperti youtube, instagram, dan lain sebagainya berperan penting dalam membangun sebuah brand, perusahaan akan membuat konsep simulasi untuk menarik minat masyarakat atau mengendalikan selera masyarakat sehingga masyarakat yang menontonnya akan merasa simulasi yang dibuat adalah realitas nyata.

Hasil dari wawancara kepada subjek yaitu individu atau kelompok apabila ingin pergi ngopi cenderung akan mencari refrensi melalui internet seperti saat ini yang mana budaya digital dengan kecepatan dan ke-instanannya, masyarakat mendapatkan kemudahan dalam menemukan apa yang menjadi daya tarik bagi mereka. Misalkan dalam hal ngopi sebagian masyarakat akan berselancar di platform-platform mainstream seperti youtube dan instagram dan tanpa disadari mereka melihat berbagai simulasi-simulasi yang dibuat untuk mempromosikan dan memperkenalkan produk-produknya.

Seiring dengan berkembangnya zaman, kedai-kedai kopi tak lagi hanya menyuguhkan kopi dan teh dengan beberapa camilan yang diangkat dari penggorengan panas dengan begitu banyak minyak yang harus ditiriskan selama beberapa menit. Akan tetapi, saat ini kedai-kedai kopi bertransformasi menjadi seperti rumah yang memberikan rasa nyaman sehingga pelanggan betah berlama-lama di dalam atau juga memberikan waktu luangnya untuk berkunjung ke kedai kopi tersebut (starbucks) untuk menikmati secangkir kopi atau produk lainnya.

Saat ini ngopi untuk sebagian masyarakat telah menjadi sebuah gaya hidup, dengan menjamurnya kedai-kedai kopi di tengah-tengah maupun di sudut-sudut kota, untuk sebagian masyarakat kegiatan ngopi dijadikan sebagai salah satu alternatif dalam mengisi waktu luang. Hal tersebut dapat dilihat dengan tidak pernah ada sepinya kedai-kedai kopi dari pelanggan setia. 
Pada saat melakukan kegiatan ngopi setiap individu akan memiliki intensitas waktu ngopi yang berbeda-beda, ada yang kecil, sedang, dan tinggi. Berdasarkan hasil dari penelitian ini sebagian masyarakat yang gemar melakukan kegiatan ngopi di starbucks memiliki intensitas dua sampai empat kali dalam satu minggu. kebiasaan ini didukung dengan perkembangan zaman yang mana kegiatan ngopi dewasa ini telah menjadi sebuah budaya populer atau budaya kekinian sehingga kegiatan ngopi telah terjadawal dengan rapi dalam diri individu atau kelompok.

Pemilihan tempat ngopi merupakan pertimbangan yang dilakukan oleh para penggiat ngopi. Dari memilih tempat yang tradisional hingga memilih tempat yang modern. Acap kali sebagian masyarakat memilih tempat ngopi yang hits atau bisa dibilang kekinian untuk mendapatkan suasana dan tempat yang nyaman serta menarik guna dijadikan latar belakang foto untuk di posting di media sosial.

Menjamurnya kedai-kedai kopi dengan berbagai brand, memaksa para pelaku usaha kedai kopi untuk berlomba-lomba menciptakan suasana serta pelayanan yang senyaman mungkin, dan juga memberikan promo-promo yang dapat menarik pelanggan. Karena, dengan hal tersebut mampu mempengaruhi sebagian masyarakat dalam menentukan pilihan tempat untuk ngopi.

Alasan kenapa mereka para penggiat ngopi memilih kedai kopi starbucks sebagai tempat ngopi antara lain karena tingkat kenyamanan dan pelayanan yang diberikan, adanya pengaruh promo-promo yang ditawarkan, adanya pengaruh nama brand, serta adanya dorongan dari luar seperti kelompok pertemanan. Dengan mengeluarkan jumlah uang yang cukup dalam dari kantong, mereka penggiat ngopi tidak merasa keberatan karena terbayarkan oleh kenyamanan, layanan yang baik, produk-produk yang memanjakan lidah, serta prestise yang tidak bisa didapat pada kedai-kedai kopi lainnya.

Saat ini muncul perasaan yang menyebar luas mengingat kerja ataupun jabatan secara tradisional menentukan kelas sosial dan begitu pula cara hidup seseorang, pada paruh kedua abad ini aktvitas-aktivitas waktu luang dan/atau kebiasaan konsumen semakin banyak dialami oleh individu-individu sebagai basis identitas sosial mereka ${ }^{16}$.

Identitas sosial adalah soal kesamaan dan perbedaan, tentang aspek personal dan sosial, 'tentang kesamaan anda dengan sejumlah orang dan apa yang membedakan anda dari orang lain ${ }^{17}$. Saat ini kegiatan ngopi merupakan salah satu alat untuk membangun images, gengsi, dan prestise bagi sebagian masyarakat, hal tersebut tidak dapat dipungkiri bahwa sebagian masyarakat masih melihat simbol sebagai keputusan dalam mengonsumsi atas dasar pemenuhan kebutuhan simbolik atau tanda yang bersifat pembentukan identitas bagi individu. ada sesuatu yang mereka cari ketika ngopi di kedai kopi starbucks yakni dengan membeli salah satu komoditi yang bersimbolkan starbucks dapat menjaga penampilan diri dan gengsi. Makna ngopi pada sebagian masyarakat sekarang ini tidak lagi menjadi satu-satunya kegiatan untuk memenuhi kebutuhan nilai fungsi, melainkan sebagai pemenuhan kebutuhan nilai simbolik yang mana pemaknaan ngopi tidak hanya untuk memenuhi kebutuhan hidup, akan tetapi juga sebagai alat untuk mengekspresikan diri.

\footnotetext{
${ }^{16}$ Chaney, Lifestyle : Sebuah Pengantar Komprehensif. Hal 186.

17 Barker, Cultural Studies. Hal 176.
} 
Setiap individu pasti memiliki sensibilitas terhadap sebuah simbol. Sensibilitas merupakan sebuah penafsiran akan sebuah objek yang dapat dimaknai oleh subjek sebagai makna yang subjektif, sehingga sensibilitas terhadap sebuah simbol dapat mempengaruhi dalam gaya hidup dan sebagai ikonografi individu atau kelompok. Untuk menemukan suatu sensibilitas bersama adalah dengan mengajukan suatu bentuk afiliasi kultural tertentu ${ }^{18}$. Tentu dalam menafsirkan atau memaknai sebuah simbol sangat bervariasi bagi setiap individu. subjek satu dengan subjek lainnya belum tentu sama dan juga belum tentu berbeda pula. Sebuah simbol berpengaruh dalam logika konsumsi untuk sebagian masyarakat, yang artinya kegiatan konsumsi tidak hanya berdasarkan pada nilai-nilai kebutuhan serta keinginan, melainkan terdapat nilai-nilai simbolik yang menjadi sebuah pertimbangan dalam menentukan kegiatan konsumsi. Saat ini setinggi apapun posisi kita di dunia sosial equivalen dengan apa yang kita konsumsi karena pada masyarakat modern konsumsi menentukan status sosial. Adapun beberapa faktor yang dapat mempengaruhi perilaku konsumsi yakni pertama adalah kelompok pertemanan, lalu yang kedua yakni trend budaya, dan yang terakhir ketiga adalah promo atau potongan harga.

Ketika individu melakukan kegiatan ngopi hal tersebut tidak terlepas dari pengaruh kelompok pertemanan. Kelompok primer yang ditandai ciri-ciri kenal-mengenal antara anggota-anggotanya serta kerja sama erat yang bersifat pribadi. Seperti misalnya keluarga, kelompok-kelompok sepermainan, rukun tetangga, dan lain-lain. Perilaku konsumsi dalam sebuah kelompok pertemanan yang dimaksud ini bisa berlaku dalam hal apapun seperti, dalam segi fashion, hobi, termasuk selera ngopi. Bukan sesuatu hal yang mengejutkan apabila dalam satu kelompok terdapat kemiripan antara satu dengan lainnya, karena mereka terbentuk dari logika konsumsi atau selera yang tidak jauh berbeda. Selanjutnya, trend budaya juga dapat mempengaruhi seseorang dalam hal konsumsi ${ }^{19}$.

Berbicara trend budaya tidak akan ada habisnya karena akan terus berkembang beriringan dengan kemajuan zaman. Pada masyarakat modern di abad ke-21 ini pergantian trend budaya begitu cepat masuk dan diikuti oleh sebagian masyarakat, hal tersebut disebabkan oleh teknologi digital yang mana masyarakat mudah mengakses berbagai platform untuk mengupdate bermacam informasi baik trend budaya, politik, ekonomi, hingga orangorang berjoget ria. Budaya saat ini dapat dikatakan sebagai kultur digital. Kultur digital adalah sebutan yang tepat untuk situasi dan kondisi abad ke-21. Betapa tidak, hampir segala tindakan dan proses interaksi hari ini praktis bergantung pada teknologi digital ${ }^{20}$.

Pada abad ke-21 ini kultur digital seperti narkoba jenis baru yang mana memberikan sebauh zat adiktif atau candu sehingga manusia tidak dapat lepas dari teknologi digital. Dengan menyuguhkan kemudahan dan kecepatan manusia merasa dimanjakan dalam budaya digital ini. Dewasa ini, kegiatan ngopi menjelma seperti menjadi sebuah trend budaya untuk sebagian masyarakat, yang mana sebagian masyarakat banyak menghabiskan waktu di kedaikedai kopi. sehingga, bagi mereka penggiat ngopi tidak ingin sampai dibilang ketinggalan zaman karena tidak mengikuti perkembangan budaya ngopi yang terjadi saat ini. Ketika ngopi mereka tidak lupa untuk memposting atau membuat story pada akun media sosial miliknya dengan

\footnotetext{
18 David Chaney, Lifestyle: Sebuah Pengantar Komprehensif (Yogyakarta: Jalasutra, 1996). Hal 209.

${ }^{19}$ Budi Sulistyowati Soekanto, Soerjono, Sosiologi Suatu Pengantar (Jakarta: Rajawali pres, 2013). Hal 110.

${ }^{20}$ Bambang Sugiharto, Kebudayaan dan Kondisi Post-Tradisi (Yogyakarta: PT Kanisius, 2019). Hal 121.
} 
tujuan untuk mempertontonkan pada pengikut-pengikutnya di akun media sosialnya. Dan yang terakhir, para pelanggan kedai kopi starbucks tidak terlepas dari pengaruh yang namanya promo atau potongan harga, mereka tergiur akan promo-promo tersebut karena sangat menarik dan mereka menganggap sangat diuntungkan dengan adanya promo dan potongan harga tersebut.

Pada masyarakat konsumsi yang mana simulacra telah dijadikan cara untuk pemenuhan kebutuhan masyarakat konsumsi atas simbol dan tanda. Sebagai masyarakat yang terbanjiri oleh citra dan informasi yang ada, maka simulacra telah membuat citra menjadi suatu hal yang diminati dan diperhatikan oleh sebagian masyarakat saat ini. Perkembangan teknologi yang sangat pesat saat ini, teknologi berperan penting dalam hal menciptakan simulacra. Contohnya media sosial, pada era saat ini media sosial tidak hanya berfungsi sebagai alat jejaring sosial yang mana menghubungkan antara satu sama lainnya yang berada dalam jarak dimana tidak memungkinkan dapat bertemu karena perbedaan lokasi yang cukup jauh. Melainkan media sosial dijadikan sebagai alat atau tempat untuk menarik masyarakat dalam kegiatan ekonomi atau konsumsi. Media sosial dibanjiri dengan berbagai iklan dengan promo yang mampu mendistorsi pikiran sehingga membuat sebagian masyarakat tertarik untuk tidak ingin ketinggalan akan promo tersebut.

\section{Analisa Teori}

Mengenai Gaya Hidup ngopi sebagai perilaku konsumsi ini apabila melihat dari kacamata Jean P Baudrillard tentang teori masyarakat konsumsi yang mana simulacra telah dijadikan cara untuk pemenuhan kebutuhan masyarakat konsumsi atas simbol dan tanda. Sebagai masyarakat yang terbanjiri oleh citra dan informasi yang ada, maka simulacra telah membuat citra menjadi suatu hal yang diminati dan diperhatikan oleh sebagian masyarakat saat ini.

Perkembangan teknologi yang pesat saat ini, teknologi berperan penting dalam hal menciptakan simulacra. Contohnya media sosial, pada era saat ini media sosial tidak hanya berfungsi sebagai alat jejaring sosial yang mana menghubungkan antara satu sama lainnya yang berada dalam jarak dimana tidak memungkinkan dapat bertemu karena perbedaan lokasi yang cukup jauh. Melainkan media sosial dijadikan sebagai alat atau tempat untuk menarik masyarakat dalam kegiatan ekonomi atau konsumsi. Media sosial dibanjiri dengan berbagai iklan dengan promo atau potongan harga yang mampu mendistorsi pikiran sehingga membuat sebagian masyarakat tertarik untuk tidak ingin ketinggalan akan promo atau potongan harga tersebut.

Ngopi pada saat ini lebih menjadi sebuah gaya hidup dan telah menjadi budaya populer. Ngopi di sebuah kedai kopi tertentu secara sadar atau tidak sadar yang akan membedakan diri individu dengan orang lain. Kegiatan ngopi tersebut telah dijadikan sebagai tindakan mendapatkan prestise untuk menunjukkan bahwa hanya orang-orang tertentu yang bisa melakukan hal tersebut. Budaya populer ngopi berkaitan erat dengan budaya konsumerisme, dimana sebagian masyarakat merasa kurang dan tidak puas dengan apa yang dimiliki. Untuk sebagian masyarakat ngopi bukanlah berdasarkan kebutuhan, melainkan keinginan bahkan gengsi. Dari uraian di atas sifat konsumsi sebagian masyarakat cenderung tidak hanya didasarkan atas kebutuhan hidup, melainkan didasarkan pada keinginan yang bisa memuaskan hasrat. 
Melihat perkembangan zaman saat ini yang mana secara sadar atau tidak sadar setiap individu memiliki gaya hidup masing-masing, sebagaimana gaya hidup merupakan pola-pola tindakan yang membedakan antara individu satu dengan individu lain dan juga merupakan representasi diri. Seiring berkembangnya zaman, mobilitas masyarakat akan semakin tinggi sehingga memunculkan rasa jenuh pada sebagian masyarakat, oleh karena itu sebagian masyarakat memilih untuk mencari kesenangan hidup atau mencari kepuasan diri seperti lebih banyak menghabiskan waktu diluar rumah, senang membeli barang-barang mahal yang disenanginya, senang bercengkerama di tempat-tempat seperti kedai kopi yang mana saat ini kedai kopi telah menjadi salah satu icon gaya hidup modern.

Perilaku ini dilakukan hingga menjadi sebuah kebiasaan bahkan sudah menjadi sebuah gaya hidup sebagian masyarakat. Misalnya penggiat ngopi yang datang ke Starbucks dapat merasakan sensasi ngopi yang eklusif karena mereka telah berada dalam suatu ruangan yang menjadikan penggiat ngopi merasa nyaman berada di dalam Starbucks. Hal ini dapat dilihat dari bagaimana kedai kopi Starbucks mendesain ruangan dengan fasilitas yang bisa dikatakan premium agar konsumen merasakan hal yang berbeda saat melakukan kegiatan konsumsi kopi.

Mengenai penelitian ini apabila melihat dari kacamata Jean P Baudrillard tentang masyarakat konsumsi, Baudrillard memfokuskan pada konsumsi yang mana ketika individu mengonsumsi maka kamu ada, sehingga saat ini sistemnya adalah objek dengan objek yang artinya masyarakat saat ini bukan lagi menjadi sebagai subjek melainkan menjadi objek yang mengobjekkan sesuatu seperti pada gaya hidup ngopi yang sedang nge-trend belakangan ini. Akibatnya, individu tidak memiliki kendali atas dirinya karena manusia tidak lagi dikelilingi oleh manusia akan tetapi manusia dikelilingi oleh simbol. Jadi, seseorang membeli komoditas tidak berdasarkan pada kebutuhan, melainkan berdasarkan pada nilai simbol (symbolic value) dan nilai tanda (sign value). Kedua nilai tersebut sebagai pertimbangan mengapa subjek memutuskan untuk membeli berbagai komoditas yang ada pada kedai kopi tersebut. Dengan adanya dorongan dari luar seperti kelompok pertemanan, trend budaya, serta iklan-iklan yang menawarkan berbagai macam promo setiap harinya, menambah dorongan pada subjek untuk memenuhi hasrat tersebut.

Subjek yang memiliki gaya hidup ngopi sebagai perilaku konsumsi berawal dari mendapatkan atau menonton simulasi-simulasi di media sosial seperti youtube. Sengaja atau tanpa sengaja, ketika kita membuka platform youtube dan memutar video, didalam video itu terdapat berbagai iklan yang disimulasikan oleh model-model yang ideal sehingga mampu mengonstruksi pikiran imajiner terhadap sebuah realitas, tanpa menghadirkan realitas itu sendiri secara esensial. Simulakra dapat dijadikan sebagai sebentuk instrumen yang mampu merubah hal-hal yang bersifat abstrak menjadi konkret dan begitu pula sebaliknya yang konkret menjadi abstrak. Setelah subjek peneliti atau sebagian masyarakat menerima simulasisimulasi yang dibuat oleh kedai kopi Starbucks, lalu mereka akan menirukan apa yang mereka lihat pada simulasi tersebut. Seiring dengan berjalannya waktu hal tersebut terus dilakukan secara berkelanjutan sehingga menjadikan subjek kehilangan kesadaran atau jati dirinya yang disebut Baudrillard yaitu ekstasi. Ekstasi merupakan kemabukan pada diri manusia yang membuatnya menjadi tidak sadar dan pada tahap ini, manusia sudah tidak lagi menjadi subjek melainkan menjadi sebuah objek dari objek. 
Hal tersebut mampu menciptakan sebuah stratifikasi sosial pada masyarakat, Baudrillard biasa menyebutnya distingsi, yaitu jarak sosial yang diakibatkan oleh pilihan selera. Sebagai contoh, konstruksi suatu individu atau kelompok atas warung kopi pinggir jalan sebagai kelas bawah, secara langsung akan berimplikasi pada penilaian kelompok tersebut terhadap mereka yang ngopi di warung kopi pinggir jalan sebagai "ndeso" atau "enggak kekinian". Berbeda dengan mereka penggiat ngopi yang acap kali memilih kedai-kedai kopi yang memiliki brand yang sudah terkenal, sebagian masyarakat akan menganggap bahwa mereka yang ngopi di kedai kopi seperti starbucks adalah individu atau kelompok kelas atas atau menengah ke atas. Dari perbedaan atau pilihan selera itulah memunculkan sebuah jarak sosial yang mana terdapat stigma selera rendah dan selera tinggi pada masyarakat dengan hanya dilihat berdasarkan konsumsinya.

\section{KESIMPULAN}

Gaya hidup ngopi telah menjadi trend di masyarakat Kota Malang saat ini, sehingga untuk sebagian masyarakat ngopi merupakan gaya hidup baru yang didalamnya terdapat perilaku konsumsi atas simbol dan tanda sebagai representasi diri. Hal tersebut dapat terlihat dari beberapa aspek yang sesuai dengan konsep mengenai perilaku konsumsi yakni subjek memiliki kecenderungan membeli komoditas tidak berdasarkan kebutuhan (need), melainkan membeli komoditas berdasarkan pada hasrat (desire) untuk memenuhi kebutuhan atas simbol dan tanda. Secara emosional, subjek memiliki tujuan untuk memperoleh prestise, menjaga images, serta meningkatkan kepercayaan diri. Beberapa faktor yang dapat mempengaruhi logika konsumsi masyarakat yaitu kelompok pertemanan, trend budaya, promo-promo yang menarik, dan sensibilitas yang dimiliki oleh masing-masing individu terhadap suatu brand atau simbol.

Perilaku konsumsi yang dilakukan penggiat ngopi begitu terlihat nyata yakni penggiat ngopi menikmati minuman yang telah dipesannya, baik itu minuman berjenis kopi ataupun minuman lainnya. Dengan memberikan pelayanan yang memuaskan, tempat yang nyaman, serta simbol yang telah mempunyai nama mampu menciptakan tanda dan citra di masyarakat sehingga menjadi pengontrol pikiran dan tingkah laku penggiat ngopi.

\section{REFERENSI}

Ahmadian, Sara, Sara Azarshahi, dan Delroy L. Paulhus. "Explaining Donald Trump via Communication Style: Grandiosity, Informality, and Dynamism." Personality and Individual Differences $107 \quad$ (1 Maret 2017): 49-53. https://doi.org/10.1016/j.paid.2016.11.018.

Baran, Stanley J. "Introduction to mass communication," 2015.

Barker, Chris. Cultural Studies. Bantul: Kreasi Wacana, 2011.

Baudrillard, Jean P. Masyarakat Konsumsi. Yogyakarta: Kreasi Wacana, 2004.

Budanti, Hartiyani Sadu, Mintasih Indriayu, dan Muhammad Sabandi. "Pengaruh lingkungan sosial dan gaya hidup terhadap perilaku konsumsi mahasiswa program studi pendidikan ekonomi FKIP UNS.” Jurnal Pendidikan Bisnis Dan Ekonomi 3, no. 2 (2017).

Chaney, David. Lifestyle: Sebuah Pengantar Komprehensif. Penerjemah. Yogyakarta: Jalasutra, 1996.

—. Lifestyle: Sebuah Pengantar Komprehensif. Yogyakarta: Jalasutra, 1996.

Darmadi, Hamid. Metode Penelitian Pendidikan dan Sosial. Bandung: Alfabeta, 2014. 
George Ritzer \& Douglas Goodman. Teori Sosiologi Modern. Jakarta: Kencana, 2003.

Mahyuddin, Mahyuddin. "Social Climber Dan Budaya Pamer: Paradoks Gaya Hidup Masyarakat Kontemporer." Jurnal Kajian Islam Interdisipliner 2, no. 2 (2019).

Peattie, Ken. "Green consumption: behavior and norms." Annual review of environment and resources 35 (2010): 195-228.

Rosenquist, J. Niels, Joanne Murabito, James H. Fowler, dan Nicholas A. Christakis. "The spread of alcohol consumption behavior in a large social network." Annals of internal medicine 152, no. 7 (2010): 426-33.

Satori, Djam'an \& Komariah, Aan. Metodologi Penelitian Kualitatif. Bandung: Alfabeta, 2009.

Shiffman, Leon, Leslie Kanuk, dan Havard Hansen. Consumer Behavior: A European Outlook. Prentice Hall, 2008.

Soekanto, Soerjono, Budi Sulistyowati. Sosiologi Suatu Pengantar. Jakarta: Rajawali pres, 2013.

Solikatun, Solikatun, Drajat Tri Kartono, dan Argyo Demartoto. "Perilaku Konsumsi Kopi Sebagai Budaya Masyarakat Konsumsi (Studi Fenomenologi Pada Peminum Kopi Di Kedai Kopi Kota Semarang).” Jurnal Analisa Sosiologi 4, no. 1 (2015).

Sugiharto, Bambang. Kebudayaan dan Kondisi Post-Tradisi. Yogyakarta: PT Kanisius, 2019.

Sugiyono. Metode Penelitian Pendidikan (Pendekatan Kuantitatif, Kualitatif, dan R\&D). Bandung: Alfabeta, 2014.

Suyanto, Bagong. Sosiologi ekonomi: Kapitalisme dan konsumsi di era masyarakat post-modernisme. Prenada Media, 2014.

Umanailo, M. Chairul Basrun, Mansyur Nawawi, dan Sukainap Pulhehe. "Konsumsi Menuju Konstruksi Masyarakat Konsumtif.” Simulacra 1, no. 2 (2018): 203-12.

Usman, Husaini \& Akbar Setiady Purnomo. Metodologi Penelitian Sosial. Jakarta: PT Bumi Aksara, 2008.

Veeger, K.J. Realitas Sosial Refleksi Filsafat Sosial Atas Hubungan Individu-Masyarakat Dalam Cakrawala Sejarah Sosiologi. Jakarta: PT Gramedia, 1986.

Welbers, Kasper, dan Michaël Opgenhaffen. "Presenting News on Social Media." Digital Journalism $7, \quad$ no. $1 \quad$ (2 Januari 2019): $45-62$. https://doi.org/10.1080/21670811.2018.1493939. 